\title{
Web-based learning media assisted by powtoon in basic mathematics course
}

\author{
Vera Dewi Susanti ${ }^{1}$, Tri Andari ${ }^{1}$, Angga Fendy Harenza ${ }^{1}$ \\ ${ }^{1}$ Universitas PGRI Madiun, Indonesia \\ $\llbracket$ vera.mathedhu@unipma.ac.id*
}

\section{Article Information}

Submitted November 26, 2019

Revised April 15, 2020

Accepted April 20, 2020

\author{
Keywords \\ Basic Mathematics; \\ Powtoon; \\ Web.
}

\begin{abstract}
Several studies had been conducted to improve the critical-thinking ability through various models, including problem approach and inquiry approach. The purpose of this study is to analyze which model is the most influential to improve students' critical-thinking skills in the last 4 years of research. This type of research is a mixed-method (quantitative-qualitative which, involved 230 students in the classroom with the problem approach and 263 students with the inquiry approach. The data collection technique used was the documentation of research reports. The data analysis used was meta-analysis through effect size calculation and Z-test. The result shows that the problem approach has a greater influence on students' critical thinking skills than the inquiry approach. This is indicated by the average values of the effect size and Z-test respectively 0.9685 and 83.122 for the problem approach and 0.7207 and 77.162 for the inquiry approach.
\end{abstract}

\section{INTRODUCTION}

Basic mathematics study is a mathematics education course taught in the third semester. One of the materials in this course is sequence and series. In learning in the classroom, the lecturer only uses LCD and is carried out classically. So learning is less interesting. This resulted in students lacking enthusiasm and less interest in learning. Lecturers should utilize online learning so that there are variations in learning. The use of the internet can increase students' academic self-confidence, academic self-reliance, and student-lecturer connection (Alshahrani et al, 2017).

Online learning has advantages when compared with classical learning since the can be accessed anytime and anywhere with positive results (Jolliffe et al, 2012; Chang, 2016; Panigrahi et al, 2018; Põldoja et al, 2012). Through online learning, students can explore more and learn more information, more learning resources, and greater opportunities for collaboration (Means et al, 2009). In contrast to classic learning where learning is done at the same time and place, online learning or learning by utilizing a website makes the time and place of learning, not an obstacle (Broadbent \& Poon, 2015; Ku \& Chang, 2011).

The web facilitates student-centered approaches, creating a motivating, active, and flexible learning environment (Own, 2007). Thus, the web can be used as a medium of mathematics learning to facilitate students in understanding the concepts of sequence and series. The web-based learning media used was Powtoon. Powtoon is a web tool used by educators to make an animation presentation with students as their target (Bachmann \& Marshall, 2019; Moraru et al, 2018). With Powtoon, an educator can make learning material according to their criteria and can add music or voice-over and add videos or pictures for up to 5 minutes for free (Moraru et al, 2018; Santos et al, 2019). In their performance, students are expected to be 
able to immediately understand the material displayed. This media also maximizes the facilities and infrastructure available in the PGRI Madiun University computer laboratory because the use of computers in learning can be maximized.

Based on research from Awalia et al (2019), it can be concluded that the learning media of Powtoon animation can provide an understanding for the fourth-grade students regarding mathematics and research by Arifah's et al (2019) concludes that by using Powtoon the mathematical critical thinking ability can be improved. Research conducted by Adkhar (2015) on the development of Powtoon-based learning media shows that the results of validation by experts was $81.3 \%$ and was declared good. The aspects of appearance and product results were $82 \%$ and the aspects of quality and effectiveness were $82.22 \%$. The results of the assessment by students for the aspects of appearance and effectiveness was $89.5 \%$. It can be concluded that the learning media was feasible to use. In this study, the Powtoon was updated and modified. The facts show that the challenges in using ICTs with the help of e-learning have been very broad with various cultures, information, and pedagogy (Diani et al, 2018; Irwandani, 2016; Islam et al 2015; Mustari et al, 2019; Lau et al, 2013). But the use of ICT is very minimal, so web-based learning is needed.

\section{METHODS}

This study was conducted on students of Mathematics Education at PGRI Madiun University in the 2018/2019 academic year. The development model used was the 4-D development model. This model consists of 4 stages of development, namely define, design, develop, and disseminate. However, in this research, the researchers only applied the first, second, and third steps due to time and cost limitations so that the disseminate stage was not carried out. The research development steps are as follows:

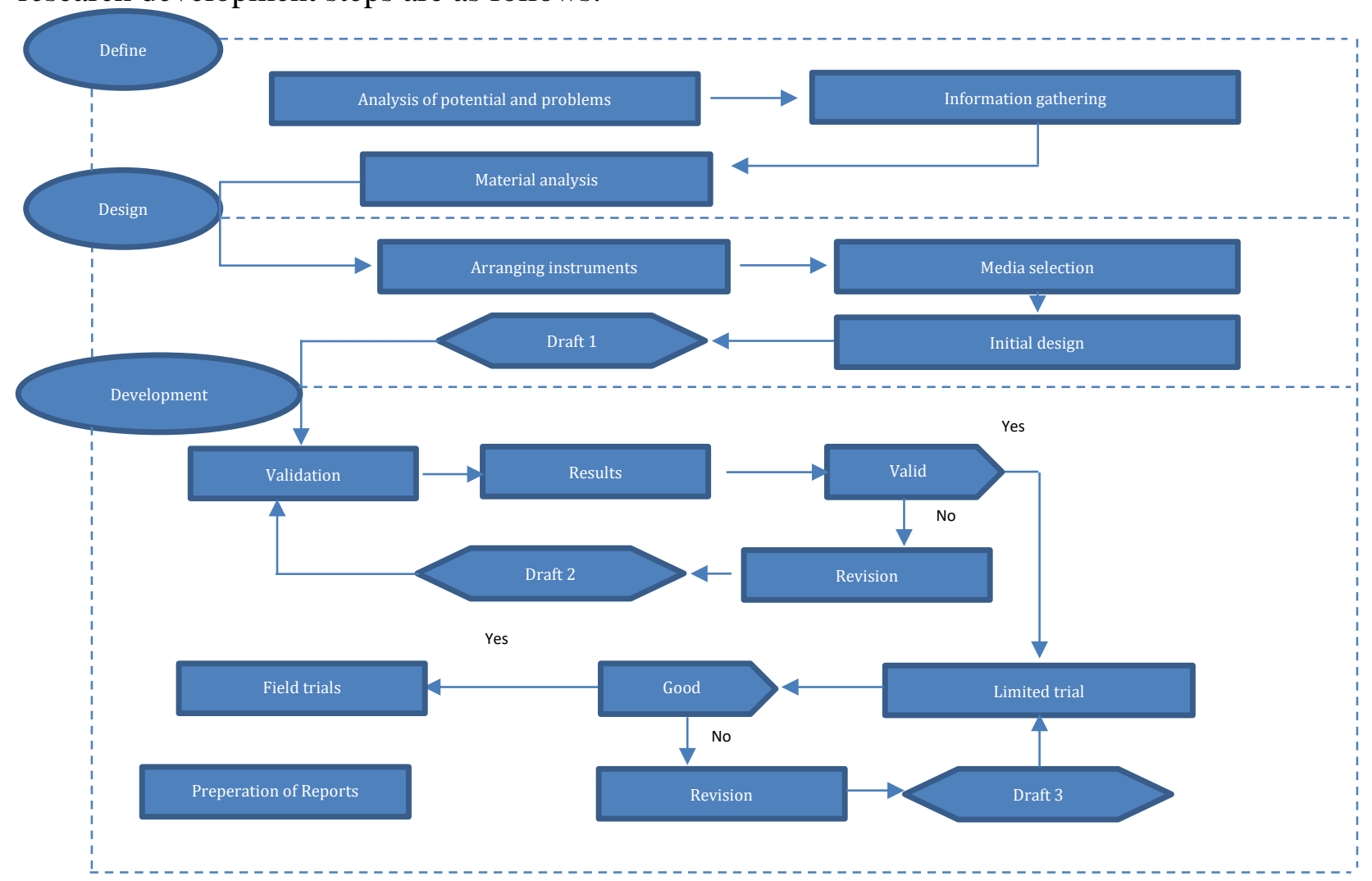

Figure 1. 4D Method Flow 


\section{Define}

The define step was carried out as follows.

1. Analysis of Potential and Problems

This stage aims to determine the potential of the research site and identify problems that occur in learning.

2. Information Gathering

It was done through field observations and interviews with Mathematics Education Lecturers.

3. Material Analysis

The formulation of learning objectives was to improve student learning achievement measured from a test of learning outcomes.

\section{Design}

The second step in this research was to prepare a prototype consisted of a drafting instrument, media preparation, and the initial design of learning media.

\section{Development}

The third step in this research was the development stage with the sequence of events as follows.

1. Validation

The purpose of this validation was to find out the advantages and disadvantages of the products that have been developed based on Akbar (2013).

In this study, the researchers referred to the validity criteria above and set the validity criteria in the range of $70.01 \%-85.00 \%$ as the minimum limit of learning media validity.

2. Media Revision

Before the product was declared valid by the validator, the researcher must still revise the product developed and produce the second draft.

3. Limited Trial

At this stage, the second draft was tested on 20 students with different cognitive abilities.

4. Field Trial

The field trial involved 46 Mathematics Education students.

\section{Validity Analysis of Learning Media}

This web-based learning media development research involved more than one expert as a validator. To find out the overall percentage, the following formula was used:

$$
V=\frac{V_{1}+V_{2}+\cdots+V_{n}}{n}=\cdots \%
$$

Web-based learning media can be declared valid (good/good enough) if the combined validity results show the results of more than $70 \%$.

\section{Practical Analysis of Learning Media}

The data of the practicality of the instructional media was obtained from the student response questionnaire. The questionnaire used was a Likert scale with a checklist method. Likert scale is used to measure people's attitudes, opinions, perceptions (Sugiyono, 2017). 
Learning media can meet the practicality criteria of the media if $\geq 70 \%$ of students classically give a positive response (Saputro, 2011). If it is less than 70\%, the researcher must make improvements based on suggestions given by students.

\section{Effectiveness Analysis of Learning Media}

Media can be said to be effective if $75 \%$ of students meet the learning mastery. It can be declared complete if the percentage of individual completeness has reached $\geq 75 \%$ with a minimum score of 75 from the overall score.

\section{RESULTS AND DISCUSSION \\ Define}

1. Potential and Problem Analysis

There is a computer laboratory with good, well-maintained, and clean conditions as well as an internet connection, projector, and whiteboard. However, the students have not maximized the facility since the use of instructional media in the teaching and learning process was only limited to using PowerPoint and most of the teaching and learning processes were conducted through lecturing and discussion methods.

2. Information Gathering

The materials chosen by the researchers to be developed in this study were sequences and series as one of the materials in the Basic Mathematics Study course. The product was developed based on the potential of students of Mathematics Education at Universitas PGRI Madiun.

3. Material Analysis

The objectives were formulated according to indicators of the sequence and series materials, among others: stating the pattern of numbers; determine arithmetic sequences and series; presents a mathematical model of real problems; determine the geometric and mathematical model of a real problem related to the materials.

\section{Design}

In this activity, the researchers conducted the preparation of instruments in the form of media validation sheets, student questionnaire responses, and learning achievement tests, media selection, and initial design of learning tools. The design of this learning media is as follows:
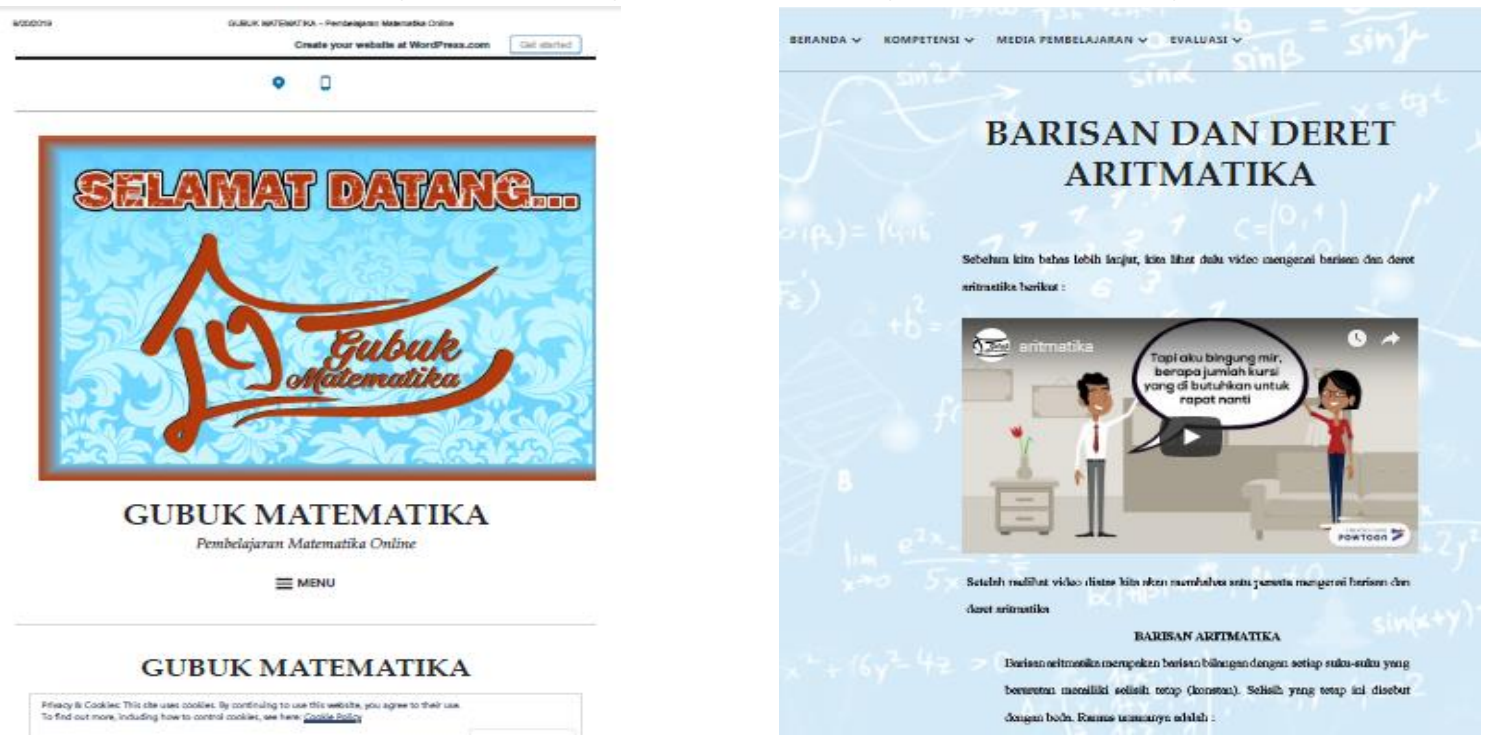


\section{BARISAN DAN DERET GEOMETRI}

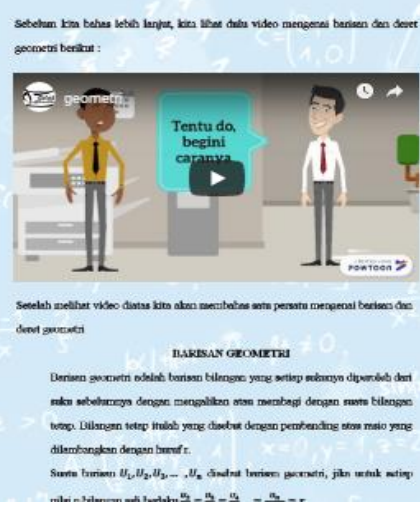

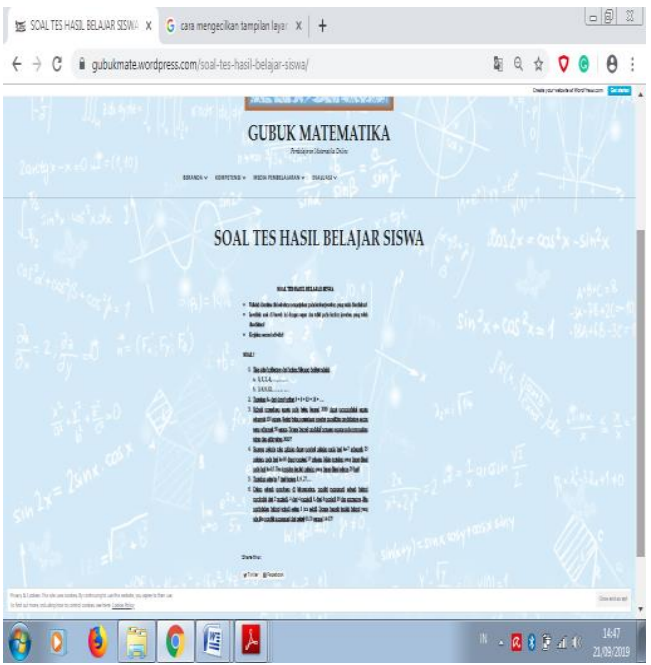

(9) D B

Figure 1. Web-based Learning Media Design Assisted by Powtoon

\section{Develop}

1. Feasibility Validation of the Test

The results obtained from the feasibility validation sheet is as follow:

Table 1. Feasibility Test Results

\begin{tabular}{ccccc}
\hline Validator & Content & Presentation & Language & Average Score \\
\hline I & 4,50 & 4,39 & 4,56 & 4,49 \\
II & 4,38 & 4,50 & 4,56 & 4,48 \\
\hline
\end{tabular}

Based on the table 1, the results of the feasibility test validation sheets by the two validators obtains an average score of 4.49 and 4.48. It states that the learning media validation sheet is appropriate to be used to assess the validity of web-based learning media with Powtoon by obtaining an average score combination of 4.48 on a scale of 5 .

2. Validation of Student Response Questionnaire

Results obtained from the validation of student questionnaire responses regarding webbased learning media with Powtoon is as follows.

Table 2. Validation Results of Students' Responses Questionnaire

\begin{tabular}{cccccc}
\hline \multirow{2}{*}{ Validator } & \multicolumn{4}{c}{ Aspect } & \multirow{2}{*}{ Score Average } \\
\cline { 2 - 5 } & Language & Compliance & Clarity & Eligibility & \\
\hline I & 4,58 & 4,75 & 4,58 & 4,42 & 4,58 \\
II & 4,50 & 4,50 & 4,67 & 4,75 & 4,60 \\
\hline
\end{tabular}

Based on the table 2, the results of the student response questionnaire validation obtains an average score of 4,58 and 4,60. It states that the student questionnaire response sheet is appropriate to be used to assess the practicality of web-based learning media with Powtoon by obtaining a combined average score of 4,49 on the scale of 5 .

3. Validation of Learning Outcomes

The validation results of the learning outcomes test are as follows.

Table 3. Test Validation Results of Learning Outcomes Test

\begin{tabular}{ccccc}
\hline \multirow{2}{*}{ Validator } & \multicolumn{3}{c}{ Aspect } & $\begin{array}{c}\text { Score } \\
\text { Average }\end{array}$ \\
\cline { 2 - 4 } & Material & Construction & Language & $80 \%$ \\
I & $90 \%$ & $93,33 \%$ & $88 \%$ & $90 \%$ \\
II & $95 \%$ & $93,33 \%$ & $88 \%$ & $91,67 \%$ \\
\hline
\end{tabular}


Based on the table 3, the results of the validation of the test can be said as good by getting the scores of $90 \%$ and $91.67 \%$. If they are combined, the percentage is $90.83 \%$ of $100 \%$ so that the test can be used to determine the effectiveness of the web-based learning media with Powtoon.

4. Validation of Learning Media

Below is the results of the validation of web-based learning media using the Powtoon application that has been rated by the validators.

Table 4. Learning Media Validation Results

\begin{tabular}{ccccc}
\hline Validator & Empirical Score & Expected Score & $\begin{array}{c}\text { Percentage of } \\
\text { Validity }\end{array}$ & $\begin{array}{c}\text { Percentage of Final } \\
\text { Validation }\end{array}$ \\
\hline I & 56 & 75 & $74,67 \%$ & $82,00 \%$ \\
II & 67 & 75 & $89,33 \%$ & \\
\hline
\end{tabular}

Based on the analysis of the validation results from the table, it shows that web-based learning media using the Powtoon application developed by researchers obtained a final validity percentage of $82.00 \%$ which is included in the quite valid category.

5. Limited Trial

The limited trial was conducted at PGRI Madiun University. Students who took the trial were limited to 20 people. The percentage of practicality obtained was $(\mathrm{P})=82.22 \%$. The results of the learning outcomes test on students in the limited trial was 81.67 so that they were declared to have met the percentage of completion which is $83.33 \%$. This shows that web-based learning media using Powtoon applications can be said as effective.

6. Field Trial

Field trials were conducted by all 82 students of Mathematics Education at PGRI Madiun University. The results of the field trial obtained through students' questionnaire responses on the aspect of practicality (P) was $82.50 \%$. The students' percentage of completeness obtained through the test was $87.50 \%$. This shows that web-based learning media using Powtoon applications can be said to be very effective.

\section{Discussion}

Learning media can be said to be feasible to use if it meets three development criteria, namely valid, practical, and effective. The following is an explanation of the three criteria.

1. The Validity of Web-Based Learning Media with Powtoon Application Learning The media is said to be valid if the combined validity score is $>70 \%$ (Akbar, 2013). The results of the combined validation by two validators for web-based learning media using the Powtoon application obtained a percentage of $82 \%$ with quite valid criteria. However, there were several suggestions proposed by the validators, one of which was an adjustment of the web background since the initial design's background was white and looked monotonous. Hence, the developed learning media can be used as alternative teaching material in mathematics learning.

2. The practicality of Web-Based Learning Media with Powtoon

Media are said to be practical if they meet the criteria of $\geq 70 \%$ of positive students' responses. The percentage of respondents who respond should at least $50 \%$ and at least $70 \%$ of them should give positive responses to the number of aspects stated (Fitria et al, 2017). The results of the questionnaire in limited trial obtained $P=82.22 \%$ which means the level of practicality was high while the results of the questionnaire responses of 
students in the field trial obtained a value of $\mathrm{P}=82.50 \%$ which means the level of practicality was high.

The results obtained were supported by positive responses from students who found it helpful to have a web-based learning media using the Powtoon application. The students were attracted by the media with a non-monotonous display and coherent material, making it easier for students to understand the material sequences and series. Setyadi \& Qohar (2017) in the development of web-based mathematics learning media on sequential and series material also states that the media used has a simple but elegant display and has a complete variety of material that enables the students to learn the materials independently.

Based on the results of practicality assessment, the learning media can be used and is easy to use. This is in line with research from Surmilasari (2012) which shows that learning media are said to be practical because all aspects observed are by the criteria, namely the score of each aspect between 66-88.

3. The Effectiveness of Web-Based Learning Media with Powtoon Wijaya (2011) suggests that forms of material, assessments, quizzes and other ways of education can also be implemented through the web, such as teacher material created in the form of presentations on the web and can be downloaded by students. Likewise, assessments and quizzes made by teachers can also be done in the same way. This shows that web media is one alternative to learning media that is complete and effective for delivering material to students, of course, to find out its effectiveness, it must be tested first. Learning media are said to be effective if the percentage of students' learning mastery is $\geq 75 \%$.

The learning achievement test scores in the limited trial showed very good results, but there was 1 student who got a score below 70 with an average percentage of mastery learning of $83.33 \%$. Although the average test scores in the field trial showed an average percentage of mastery learning at $87.50 \%, 2$ students scored below 70 . This shows that web-based learning media using Powtoon applications can be said to be effective. This is in line with the research of (Irianti \& Wijaya, 2017) which states that the development of Moodle-based E-Learning media on the subject of the VIII grade circle of junior high schools based on the effectiveness aspect in terms of the implementation of learning meets the effective criteria with an average percentage of $86.8 \%$.

This result is supported by students' responses during learning activities that show students' thinking ability to be balanced because Powtoon application allows students to understand the concepts of sequences and series directly through learning videos constructed based on real-life problems. According to research by Santos et al (2019) Powtoon is used by students to do tutorials on debate models, conduct courses, and to train students' critical thinking.

In line with this, Wijaya (2011) states that in developing a web-based E-Learning learning model with the principle of E-Pedagogy in improving learning outcomes, there is a quite striking difference from previous learning. In web-based E-Learning, students are balanced and equitable, their thinking abilities can be further optimized according to each student's ability level which is not present in conventional learning models. Based 
on the results of the effectiveness, the learning media that have been developed are effective, so that the development of learning media can be used for learning purposes.

Based on the description above, it can be concluded that the web-based learning media using the Powtoon application is suitable for use in learning because it meets the development criteria of valid, practical, and effective. In line with the research by Rynson W. H. Lau, Neil Y. Yen, Frederick Li \& Benjamin Wah that web-assisted learning offers students to match their learning styles that lead to an increase in their learning effectiveness and as future trends from a pedagogical and technological perspective (Lau et al, 2013).

\section{CONCLUSIONS}

From the results of the development, the developed learning media can be declared as feasible with quite valid criteria based on the average results obtained from the media validation questionnaire that was $82.00 \%$. The level of practicality with an average score of $82.22 \%$ indicated that students' responses toward web-based learning media were high. The average score obtained from the students' questionnaire responses in the field trial was $82.50 \%$ which was also in the high category. The level of effectiveness met the effectiveness criteria with the average results obtained from the average achievement test in the limited trial of 81.67. Whereas in the field trial, the average learning achievement test was 81.25.

\section{AUTHOR CONTRIBUTIONS STATEMENT}

VDS worked as the principal investigator for this research project. This study was designed, conceptualized and carried out by him. He has made major contributions in designing theoretical frameworks and reviewing literature related to research. TA and AFH have become an important part in the development process of the developed media.

\section{REFERENCES}

Adkhar, B. I. (2015). Pengembangan media video animasi pembelajaran berbasis powtoon pada kelas 2 mata pelajaran ilmu pengetahuan alam di SD labschool UNNES. (Doctoral dissertation, Universitas Negeri Semarang)

Akbar, S. (2013). Instrumen perangkat pembelajaran. Bandung: PT Remaja Posdakarya.

Alshahrani, S., Ahmed, E., \& Ward, R. (2017). The influence of online resources on studentlecturer relationship in higher education: A comparison study. Journal of Computers in Education, 4(2), 87-106.

Arifah, U., Suyitno, H., \& Dewi, N. R. (2019). Kajian teori: Meningkatkan kemampuan berpikir kritis matematis melalui model brain based learning berbantuan powtoon. PRISMA, Prosiding Seminar Nasional Matematika, 2, 718-723.

Awalia, I., Pamungkas, A. S., \& Trian, P. (2019). Pengembangan media pembelajaran animasi powtoon pada mata pelajaran matematika di kelas IV SD. Kreano, Jurnal Matematika Kreatif-Inovatif, 10(1), 49-56.

Bachmann, G., \& Marshall, I. (2019). Transgender youth: Explaining hormonal affirmation treatment via powtoon format-(MTF). Fertility and Sterility, 112(3), e430. 
Broadbent, J., \& Poon, W. L. (2015). Self-regulated learning strategies \& academic achievement in online higher education learning environments: A systematic review. Internet and Higher Education, 27, 1-13.

Chang, V. (2016). Review and discussion: E-learning for academia and industry. International Journal of Information Management, 36(3), 476-485.

Diani, R., Yuberti, Y., \& Syarlisjiswan, M. R. (2018). Web-enhanced course based on problembased learning (PBL): Development of interactive learning media for basic physics II. Jurnal Ilmiah Pendidikan Fisika Al-Biruni, 7(1), 105-116.

Fitria, A. D., Mustami, M. K., \& Taufiq, A. U. (2017). Pengembangan media gambar berbasis potensi lokal pada pembelajaran materi keanekaragaman hayati di kelas X di SMA 1 pitu riase kab. Sidrap. AULADUNA: Jurnal Pendidikan Dasar Islam, 4(2), 14-28.

Irianti, N. P., \& Wijaya, E. M. S. (2017). Pengembanagn media pembelajaran e-learning berbasis moodle pada pokok bahasan lingkaran kelas VIII SMP. JIPM (Jurnal Ilmiah Pendidikan Matematika), 5(2), 122-130.

Irwandani, I. (2016). Potensi media sosial dalam mempopulerkan konten sains islam. Tadris: Jurnal Keguruan Dan Ilmu Tarbiyah, 1(2), 173-177.

Islam, N., Beer, M., \& Slack, F. (2015). E-learning challenges faced by academics in higher education: A literature review. Journal of Education and Training Studies, 3(5), 102112.

Jolliffe, A., Ritter, J., \& Stevens, D. (2012). The online learning handbook: Developing and using web-based learning. Routledge.

Ku, D. T., \& Chang, C. S. (2011). The effect of academic discipline and gender difference on Taiwanese college students' learning styles and strategies in web-based learning environments. Turkish Online Journal of Educational Technology, 10(3), 265-272.

Lau, R. W. H., Yen, N. Y., Li, F., \& Wah, B. (2013). Recent development in multimedia elearning technologies. World Wide Web, 17(2), 189-198.

Means, B., Toyama, Y., Murphy, R., Bakia, M., \& Jones, K. (2009). Evaluation of evidencebased practices in online learning: A meta-analysis and review of online learning studies [Monograph]. Centre for Learning Technology.

Moraru, P., Silva, B., Allen, I., Dias, J., Ribeiro, R., Pinho, M., . . Bento, M. (2018). Teaching toolkit: Innovative use of mobile devices in the educational process. ISBN 978-9898525-58-1

Mustari, M., Hoya, A. L., Akmansyah, M., Diani, R., \& Asyhari, A. (2019). Development of elearning based blogs on global warming subject. Journal of Physics: Conference Series, 1155(1).

Own, Z. (2007). The application of an adaptive, web-based learning environment on oxidationreduction reactions. International Journal of Science and Mathematics Education, 8(1), $1-23$.

Panigrahi, R., Srivastava, P. R., \& Sharma, D. (2018). Online learning: Adoption, continuance, and learning outcome a review of literature. International Journal of Information 
Management, 43, 1-14.

Põldoja, H., Väljataga, T., Laanpere, M., \& Tammets, K. (2012). Web-based self- and peerassessment of teachers' digital competencies. World Wide Web, 17(2), 255-269.

Santos, L., Fernandes, N., Jorge, G., Magalhaes, L., Brochado, M., Rebelo, M., \& Vilas-Boas, B. (2019). MISO - motion in the science ocean - erasmus + project - use of powtoon, easyclass and mentimeter in a high school debate using the the WSDC model. The Eurasia Proceedings of Educational and Social Science, 13, 24-36.

Saputro. (2011). Pengembangan perangkat pembelajaran matematika dengan Media Visual basic net 2008 pada materi lingkaran di kelas VIIIB MTs negeri Krian Sidoarjo. (Doctoral dissertation, IAIN Sunan Ampel Surabaya).

Setyadi, D., \& Qohar, A. (2017). Pengembangan media pembelajaran matematika berbasis web pada materi barisan dan deret. Kreano, Jurnal Matematika Kreatif-Inovatif, 8(1), 1-7.

Sugiyono, S. (2017). Metode penelitian kebijakan: Pendekatan kuantitatif, kualitatif, kombinasi, $R \& D$, dan penelitian evaluasi. Bandung: Alfabeta.

Surmilasari, N. (2012). Pengembangan LKS matematika berbasis konstruktivisme untuk pembelajaran materi perkalian dua matriks di kelas XII SMA. In Prosiding Seminar Nasional Matematika dan Pendidikan Matematika FMIPA UNY (pp. 635-642).

Wijaya, M. (2011). Pengembangan model pembelajaran e-learning berbasis web dengan prinsip e-pedagogy dalam meningkatkan hasil belajar. (Doctoral dissertation, Universitas Pendidikan Indonesia). 